\section{Omfattende og godt om arvelige hjertesykdommer}

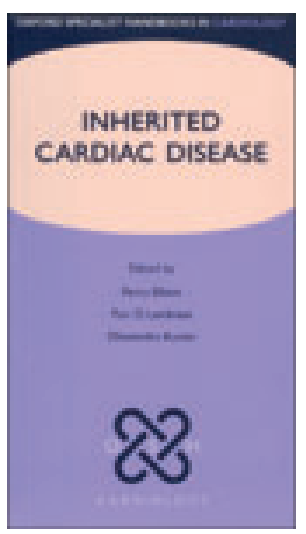

Perry Elliott, Pier D. Lambiase,

Dhavendra Kumar, red.

Inherited cardiac disease

424 s, tab, ill. Oxford: Oxford University Press, 2011. Pris GBP 40

ISBN 978-0-19-955968-8

Målgruppen er alle som arbeider med arvelige hjertesykdommer, først og fremst kardiologer, barneleger og genetikere. Boken er ikke bare ment for spesialister, men kan med fordel også leses av annet fagpersonell som er interessert i arvelige sykdommer. Formatet er hendig og passer fint i frakkelommen.

Oppbygningen er god - forfatterne går igjennom genetiske prinsipper, arvegang og veiledning, i tillegg til de diagnostiske metodene for DNA-analyse. Videre omtaler de spesifikke hjertesykdommer, som de klassiske medfødte hjertesykdommene, fulgt av kardiomyopatier og ionekanalsykdommer. Mye plass er også satt av til arvelige sykdommer med potensial for hjerteaffeksjon, slik som bindevevssykdommer (f.eks. Marfans syndrom), familiær hyperkolesterolemi, muskelsykdommer og mitokondriesykdommer.

Kapitlene er godt strukturert og har mange avsnitt i punktform med huskelister. Det er få illustrasjoner; de fleste er enkle og hjelper leseren, men noen er for sparsomt forklart. Papiret er tynt, og skriften er liten.

Innledningen er en fin introduksjon for klinikere som trenger en oversikt over genetikk. Etiske aspekter ved gentesting er godt ivaretatt og utførlig beskrevet. Lovmessige forhold for gentesting er kort beskrevet og baserer seg på britiske forhold. Dette er ikke noe problem - avsnittene er allmenngyldige, og prinsippene samsvarer stort sett med norske forhold. De medfødte hjertesykdommene er kort omtalt. Bidragsyterne har lagt vekt på arvelighet, når det er indisert med DNA-test av foreldre og risikoen for gjentakelse av sykdom for neste barn.

Hoveddelen omhandler kardiomyopatier og sykdommer der arvegangen ofte følger de mendelske lover. I tillegg er det tatt med sykdommer som vi vanligvis betrakter å være uten streng arvelighet, f.eks. koronarsykdom, hjerneslag og torakal aortaaneurisme, og hvilke spesielle tilstander man bør tenke på hvis de oppstår familiært. Til tross for kortfattet språklig form går forfatterne i dybden og gir grundig informasjon om ulike diagnostiske metoder, behandlingsmuligheter og ikke minst risikostratifisering.

Alt $i$ alt er boken nyttig og velegnet for klinikere som behandler pasienter med hjertesykdom og andre arvelige sykdommer der hjerteaffeksjon er mulig. Den er omfattende og mer egnet som oppslagsbok enn som lærebok til å lese fra perm til perm.

Kristina Hermann Haugaa

Kardiologisk avdeling

Oslo universitetssykehus, Rikshospitalet

\section{lkke godt nok om medisinsk sosiologi}

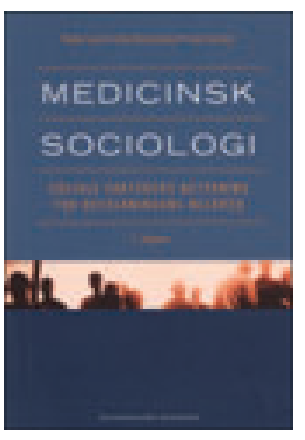

Rikke Lund, Ulla Christensen, Lars Iversen Medicinsk sociologi

Sociale faktorers betydning for befolkningens helbred. 2. utg. 292 s, tab, ill. København: Munksgaard Danmark, 2011. Pris DKK 378 ISBN 978-87-628-0944-4

Dette er en artikkelsamling på dansk om sammenhengen mellom samfunn og helse, spesielt hvordan sosiale forhold har betydning for folks helse. Boken er en revidert versjon av en over 20 år gammel bok. Flertallet av forfatterne er leger, men flere samfunnsvitere og en statistiker er også blant bidragsyterne. Alle faggrupper innenfor medisin og helse er definert som målgruppe.

Forfatterne begynner med et femsiders innledende kapittel hvor de presenterer disposisjon, grunnideer og grunnleggende helseforståelse (den biopsykososiale modellen). Deretter følger et teoretisk bidrag om sosial kapital i relasjon til helse. Så kommer en rekke kapitler (3-11) hvor forfatterne tar for seg helse i forhold til ulike sosiale og samfunnsmessige faktorer: sosiale relasjoner, livsstil (sosiale gradienter), arbeid, sosial utsatthet, migrasjon/etnisitet, kjønn, livsløp og stress. Til slutt kommer to kapitler med et litt annet søkelys; et om fysiologiske forklaringer på helseskadelig stress og et empirisk bidrag om dødelighet og sykelighet i Danmark $i$ et historisk perspektiv. Redaktørene presenterer disposisjonen som tredelt, og som en vandring fra sosiale strukturer (makronivå) til det liv den enkelte utfolder seg i (mikronivå), og til slutt til temaet stress. Ellers er det et fyldig stikkordregister og litteraturlister (sistnevnte følger de enkelte bidragene).

Boken er ryddig, og de ulike bidragene utfyller hverandre godt. En rød tråd er sosioøkonomisk ulikhet i helse, som knyttes både til utdanning, arbeid, inntekt, sosiale nettverk, geografi og kjønn. Boken har dagsaktuelle temaer som gjør den relevant for dem som arbeider med tjenesteyting i helsesektoren. Flere av bidragene holder et høyt nivå.

Det er likevel et savn at redaktørene ikke har gitt mer plass til overordnede og sammenfattende drøftinger. Hvis vi ser alle artiklene under ett, hva ser vi da? Drøftinger av dette og liknende spørsmål bidrar til å legitimere at artikler blir samlet mellom to permer og ikke publisert i et tidsskrift. Når denne delen begrenser seg til fem sider i en innledning, blir det for knapt, og det resulterer $i$ at enkelte uklarheter blir stående. Blant annet er det en kategoriforskjell mellom tre sykdomsmodeller som forfatterne presenterer: Mens to av modellene angår ståsted (den syke og profesjonene), angår den tredje den sykes funksjonsnivå (som ikke er et ståsted, men kan ses fra ulike ståsteder). Kulturens sykdomsforståelse er et ståsted som ikke er tatt med i modellen, og det kunne den med fordel ha vært. Diskusjonen av disse tre modellene er også dårlig integrert med presentasjonen av den biopsykososiale modellen.

Alt i alt er dette en interessant og aktuell bok som er verdt å lese, men det finnes mange liknende bøker, både på norsk og engelsk, som gjør at det for norske leger og medisinstudenter trolig finnes bedre alternativer.

\section{Olaug S. Lian}

Institutt for samfunnsmedisin

Universitetet i Troms $\varnothing$ 